\title{
Design, synthesis and preliminary evaluation of peptidomimetic inhibitors of HIV aspartic protease with an epoxyalcohol core
}

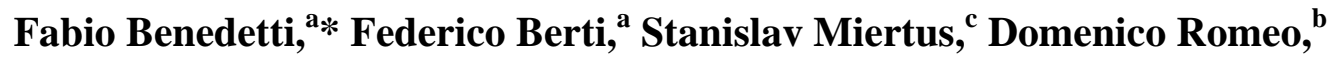 \\ Francesca Schillani, ${ }^{a}$ and Alessandro Tossi ${ }^{b}$ \\ ${ }^{a}$ Dipartimento di Scienze Chimiche and ${ }^{b}$ Dipartimento di Biochimica, Biofisica e Chimica delle \\ Macromolecole, Università di Trieste, via L. Giorgieri 1, I-34127 Trieste, Italy \\ ${ }^{c}$ ICS-UNIDO, AREA Science Park, I-34012 Trieste, Italy \\ E-mail: benedett@units.it
}

Dedicated to Professor Branko Stanovnik on his $65^{\text {th }}$ birthday

(received 31 Aug 03; accepted 31 Oct 03; published on the web 23 Nov 03)

\begin{abstract}
Two peptidomimetic inhibitors based on a novel epoxyalcohol core were designed to target the epoxide ring at the catalytic aspartates of HIV-protease for irreversible inhibition of the enzyme. The inhibitors were synthesized with a multi-step approach which includes Horner-Emmons olefination of a phenylalanine-derived phosphono ketone, stereoselective reduction of the resulting trans-enones to allylic alcohols and syn-epoxidation of the latters. The epoxyalcohols thus obtained were assayed for their ability to inhibit HIV-PR and were shown to inhibit the protease with $\mathrm{IC}_{50}$ values of 39 and $150 \mu \mathrm{M}$, respectively. This confirms that the designed epoxides are recognised with fairly good affinity by the enzyme's active site, a pre-requisite for selective irreversible inhibition.
\end{abstract}

Keywords: HIV, aspartic protease, inhibitor, epoxide, peptidomimetic

\section{Introduction}

The human immunodeficiency virus (HIV) is the causative agent of the acquired immunodeficiency sindrome (AIDS); in the last decade much effort has been devoted to the development of efficient chemotherapics that can control the progress of the viral infection. ${ }^{1,2}$ Inhibitors of the HIV protease (HIV-PR), the enzyme responsible for proteolytic cleavage of the viral gag-pol polyprotein into its functional subunits, have been shown to be effective in preventing viral maturation ${ }^{3,4}$ and following intense research in this field six HIV-PR inhibitors have been approved for clinical use while many more are in the pipeline and awaiting clearance. $^{1-5}$ 
HIV-PR is an aspartyl protease whose active form is a symmetric homodimer of a chain consisting of 99-residues. The two subunits are correlated by a $C_{2}$ axis running across the binding site, and each monomer contributes a catalytic aspartyl residue. ${ }^{6,7}$ The peptide substrate is recognized in an extended conformation ${ }^{8}$ and the aspartate diad is responsible for the catalytic acceleration through a general acid / general base mechanism. ${ }^{9}$ HIV-PR inhibitors used in the clinical practice are peptidomimetics that reversibly inhibit the enzyme by competing with the substrate for the active site. The availability of structural information from X-ray crystallography and previous knowledge accumulated in the development of inhibitors of other aspartic proteases have greatly facilitated the design of potent inhibitors with $\mathrm{IC}_{50}$ values in the nanomolar and subnanomolar range. ${ }^{3,4,9-14}$ A major problem in anti-AIDS therapy, however, is the rapid emergence of drug-resistant mutants, a consequence of the high rate of replication of the virus and of the high error rate of reverse transcription. ${ }^{1-4,9}$ Mutations at, or near, the binding site may decrease the enzyme's affinity for an inhibitor, without significantly altering its activity, leading to functional mutant proteases that are resistant to reversible inhibitors. An alternative approach to the inactivation of HIV-PR is thus based on irreversible inhibitors; these should be less sensitive to mutations because a reduced affinity will lower the equilibrium concentration of the enzyme-inhibitor complex and slow down, but not necessarily stop, the reaction between the inhibitor and the enzyme leading to its inactivation.

Targeting the active site of aspartyl proteases for irreversible inhibition requires a potent electrophile, which must be able to alkylate the carboxylate group notwithstanding its inherent low nucleophilicity. At the same time the electrophile must be sufficiently selective not to interact with other potential targets. The combination of these two contrasting properties makes the design of efficient irreversible inhibitors a challenging problem.

It was shown some years ago that 3-(4-nitro)phenoxy-1,2-epoxypropane (EPNP, 1), a general inhibitor of aspartyl proteases, irreversibly inactivates HIV-PR by alkylating the active site Asp25 $\left(K_{\text {inact }}=11 \mathrm{mM}\right) \cdot{ }^{15,16}$ Not surprisingly, however, this activated epoxide is not selective and its reaction with DNA has been recently demonstrated. ${ }^{17}$ In 1994, Ortiz de Montellano and coworkers reported the irreversible inhibition of HIV-PR by epoxides and $\alpha, \beta$-unsaturated ketones structurally derived from haloperidol. ${ }^{18}$ The same group later showed that only the haloperidol derived epoxides selectively alkylate one of the active-site aspartate residues, while reaction of the protease with the more reactive enones or ynones resulted in alkylation of cystein residues (Cys67 and Cys95) and the N-terminal proline in both subunits. ${ }^{19}$ Haloperidol derived epoxides include $2\left(\mathrm{~K}_{\text {inact }}=521 \mu \mathrm{M}\right)^{16}$ and the simplified inhibitor $3\left(\mathrm{~K}_{\text {inact }}=65 \mu \mathrm{M}\right){ }^{19}$

Based on these reports, a number of designed inhibitors have been described in which the epoxide is incorporated in a peptide or peptidomimetic structure in order to improve the inhibitor's binding affinity; ${ }^{20-24}$ some examples (4-6) are reported in Figure 1. A mechanism for the alkylation of the catalytic aspartate, involving hydrogen-bond assisted ring opening of the bound epoxide has also been proposed. ${ }^{25,26}$ These studies clearly indicate the potential of epoxides as selective, irreversible HIV-PR inhibitors and led us to investigate novel peptidomimetic structures which combine an epoxide ring with flanking residues derived from 
our previous experience on competitive HIV-PR inhibitors. ${ }^{27-29}$ Herein we describe the design, synthesis and preliminary evaluation of HIV-PR inhibitors based on a novel epoxyalcohol motif.

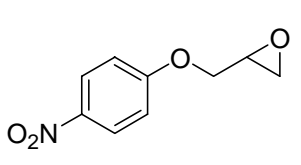

1

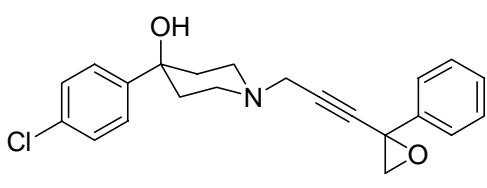

2

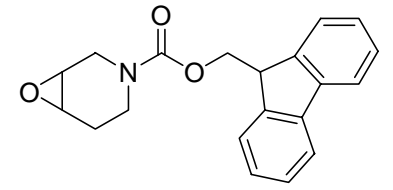

3

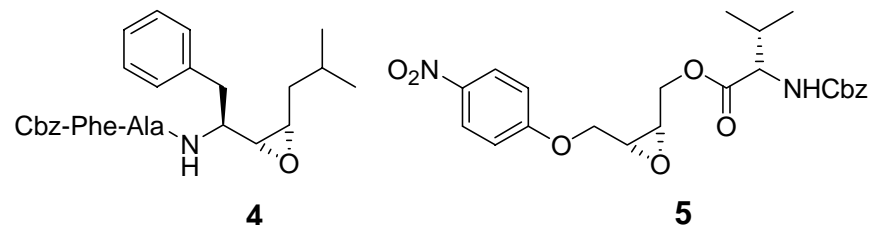

4

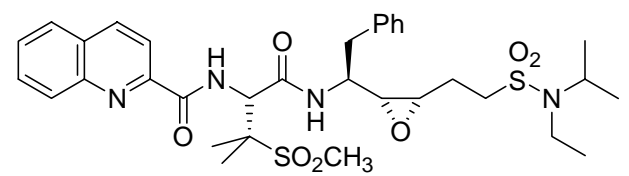

6

Figure 1. Epoxide-based irreversible inhibitors of HIV-PR.

\section{Results and Discussion}

Design. Structural studies of complexes of HIV-PR with peptide substrates and peptidomimetic inhibitors have allowed the conclusion that in the extended conformation in which the substrate is recognized by the protease, essential binding interactions are established between three residues on each side of the scissile bond and corresponding subsites of the enzyme. ${ }^{8,9,13}$ According to standard nomenclature, the residues are designated P3, P2, P1, P1', P2', P3' while the corresponding subsites are referred to as S3--S3'.

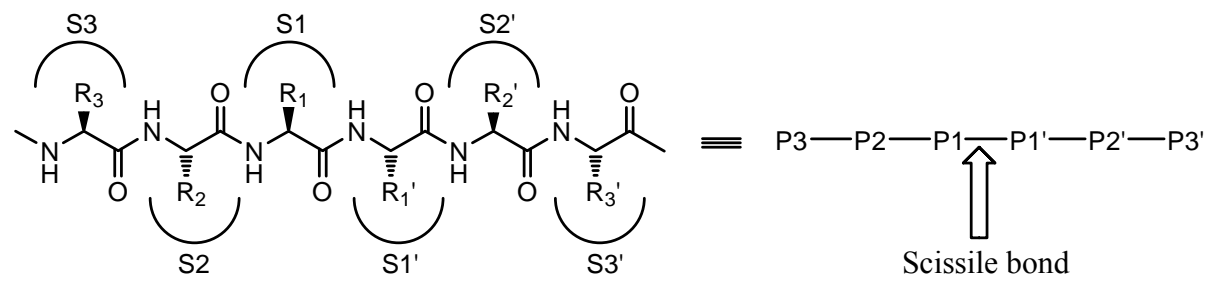

Efficient peptidomimetic inhibitors can be obtained by replacing the scissile peptide bond P1-P1' with a non-scissile dipeptide isostere $\Psi[\mathrm{P} 1-\mathrm{P} 1$ '] and optimizing the P3- -P3' residues for binding to the corresponding subsites. ${ }^{9,13,14}$ Hydroxyethylene and dihydroxyethylene dipeptide isosteres $^{30}$ are widely used in the design of aspartic protease inhibitors as the enzyme-inhibitor complex is stabilized by interactions between the catalytic aspartates and the hydroxy groups of the isostere, which are believed to mimic the tetrahedral transition state for amide hydrolysis. ${ }^{9,13}$ We thus decided to incorporate a hydroxy group in the design of our inhibitors, whose function is to bind the active site carboxylates and hold the epoxide in the correct position for irreversible alkylation (Figure 2). 


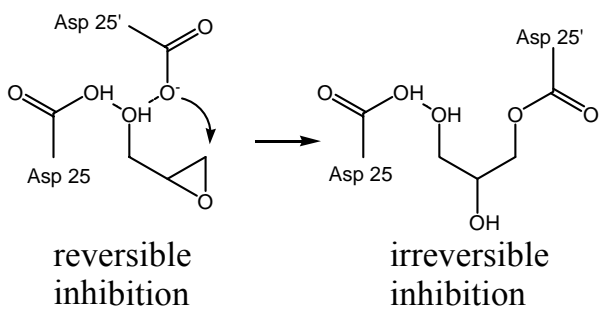

Figure 2. Proposed mechanism of inactivation of HIV-PR by epoxyalcohol inhibitors.

Epoxyalcohol inhibitors 7 and 8 (Figure 3) were designed starting from the structure of hexameric inhibitor PV, based on a dihydroxyethylene isostere, which inhibits HIV-PR with an $\mathrm{IC}_{50}$ of $15 \mathrm{nM}^{28}$ This $C_{2}$-symmetric inhibitor has Phe in $\mathrm{P} 1$ and $\mathrm{P} 1$ ', an arrangement that has been shown to be most effective for HIV-PR inhibition, ${ }^{9,13,14}$ Val in P2, P2' and is capped with phenoxyacetic acid (Poa) in both $\mathrm{P} 3$ and $\mathrm{P} 3$ '. The latter residue has a low molecular weight and reduced peptide character while preserving hydrophobic interactions with the S3, S3' subsites. In 7 an epoxide ring is grafted on the P3--P1 portion of PV so as to generate an epoxyalcohol with the same configuration as in the central diol of PV. An aminomethyl group on the trans epoxide ring allows the introduction of a second Poa residue in a position intermediate between $\mathrm{P} 1^{\prime}$ ' and P2'; inhibitor 7 is thus expected to interact with the S3, S2, S1 and S1'/S2' subsites of the protease. While hexameric pseudopeptides are optimal for binding to the protease's active site, we have shown that pentameric and even tetrameric structures based on hydroxyethylene ${ }^{29}$ and dihydroxyethylene isostere ${ }^{28}$ still provide sufficient binding interactions to inhibit the protease with $\mathrm{IC}_{50}$ values in the $\mathrm{nM}$ to $\mu \mathrm{M}$ range. Since low molecular weight and reduced peptide character are important for the inhibitor's pharmacological properties, we decided to synthesize also the simplified epoxyalcohol 8, in which P3 has been omitted and Val is replaced by Poa in P2.
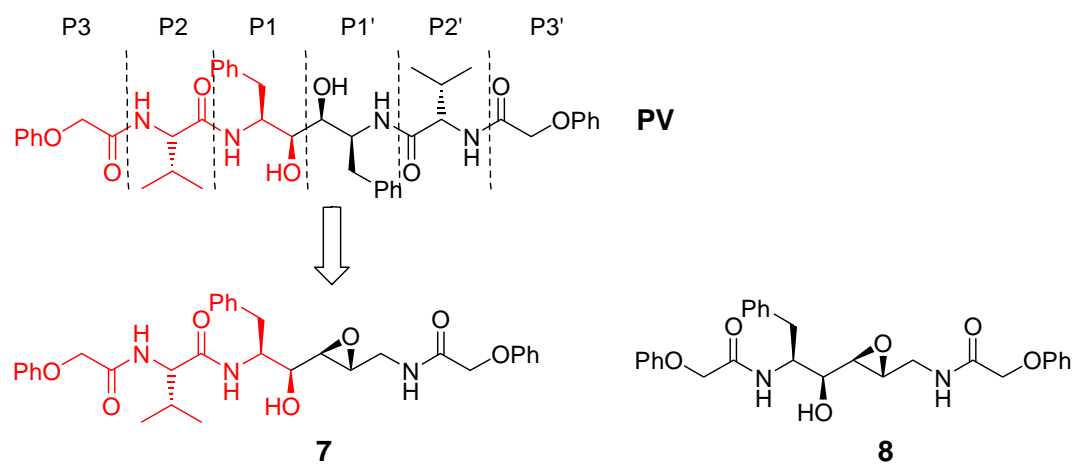

Figure 3. HIV-PR inhibitor PV and epoxyalcohol inhibitors 7, 8. The P3-P1 portion common to both $\mathbf{P V}$ and $\mathbf{7}$ is highlighted in red. 
Synthesis. The approach to epoxyalcohols 7, 8 started with the synthesis of precursors 11, 13, 15a (Scheme 1). Phenoxyacetic acid was activated with N-hydroxysuccinimide (NHS) and condensed with aminoacetaldehyde diethyl acetal giving the protected phenoxyacetamido acetaldehyde 10. Hydrolysis of the latter gave the required aldehyde 11. Condensation of PoaOsu 9 with L-valine gave phenoxyacetamido valine 12 (Poa-Val) which, in turn, was condensed with NHS to give the activated ester 13 (Poa-Val-Osu). The methyl ester of phenoxyacetyl phenylalanine 14 was obtained from the methyl ester of the amino acid and Poa-Osu 9 and then converted into the phosphonoketone 15 a by reaction with an excess of lithiated dimethyl methylphosphonate. ${ }^{31}$

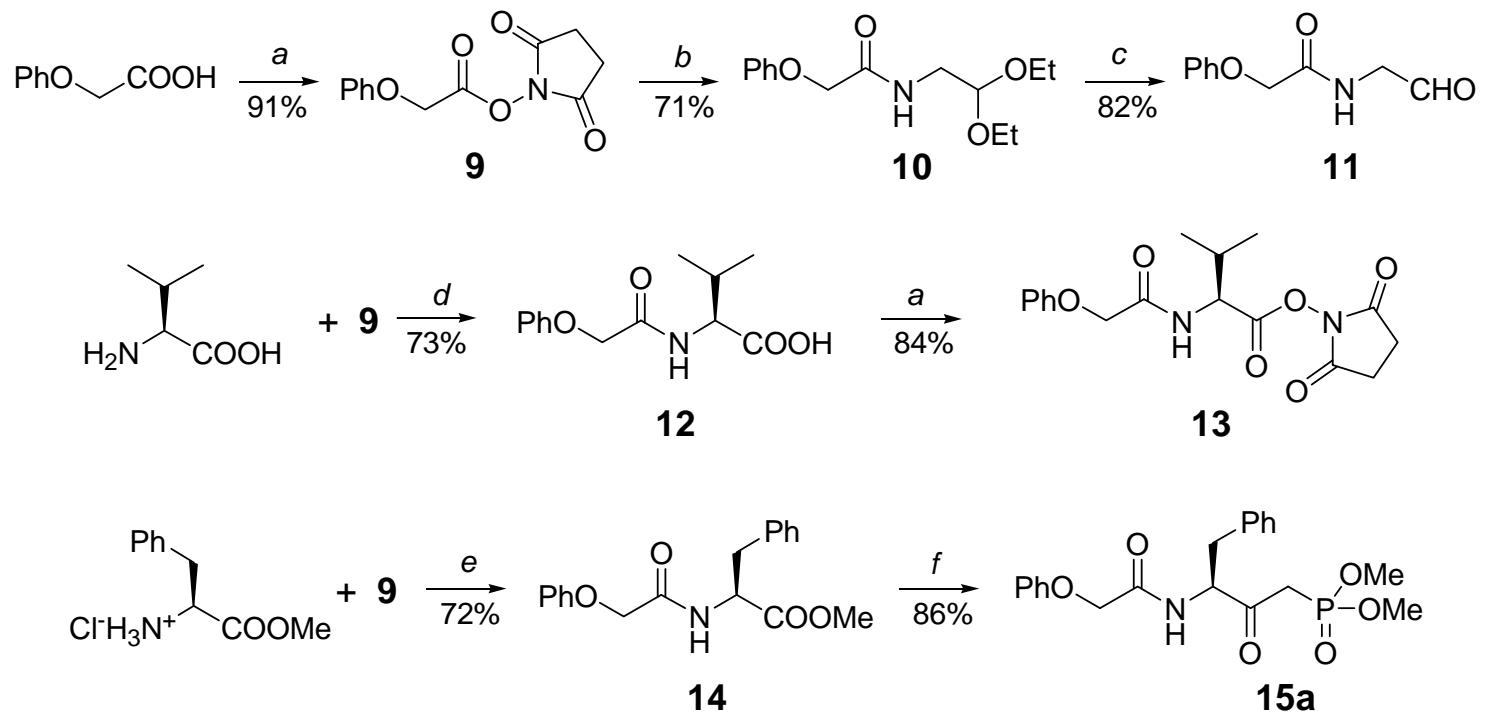

$a$ - NHS, DCC, dioxane, $25{ }^{\circ} \mathrm{C} ; b$ - 2,2-diethoxyethylamine, $\mathrm{CH}_{2} \mathrm{Cl}_{2}, 25{ }^{\circ} \mathrm{C} ; c$ - TFA, $\mathrm{CH}_{2} \mathrm{Cl}_{2} / \mathrm{H}_{2} \mathrm{O}, 25^{\circ} \mathrm{C}$; $d$ - dioxane $/ \mathrm{H}_{2} \mathrm{O}, \mathrm{NaOH}$, then $\mathrm{HCl} 25^{\circ} \mathrm{C} ; e-\mathrm{NEt}_{3}, \mathrm{CH}_{2} \mathrm{Cl}_{2}, 25^{\circ} \mathrm{C}$; $f$ - $\mathrm{LiCH}_{2} \mathrm{P}(\mathrm{O})(\mathrm{OMe})_{2}$, THF, $-78^{\circ} \mathrm{C}$.

Scheme 1. Synthesis of precursors.

The next steps (Scheme 2) follow the general approach previously described ${ }^{32}$ for the synthesis of diaminodiol dipeptide isosteres. Thus, Horner-Emmons olefination of phosphonoketone 15a with the aldehyde 11, under the conditions described by Mikolajczik, ${ }^{33}$ gave the $E$ enone 16a in $78 \%$ yield (Scheme 2). The $E$ geometry of the double bond was confirmed by the $16 \mathrm{~Hz}$ coupling constant between the vinyl protons in the ${ }^{1} \mathrm{H}$ NMR spectrum of 16a. Similarly, the N-Boc enone 16b, was obtained from 11 and the corresponding Bocprotected phosphonoketone 15b. ${ }^{32}$ The enones 16 were then reduced with sodium borohydride in methanol, at $0{ }^{\circ} \mathrm{C}$, giving the allylic alcohols 17a,b as $3: 1$ mixtures of diastereoisomers. Earlier work had allowed to establish that, in the NMR of allylic alcohols closely related to $\mathbf{1 7},{ }^{32,34}$ the $\mathrm{H}-4$ vinylic proton of the $S, R$ isomer (Scheme 2) always resonates at higher field than the 
corresponding proton of the $S, S$-isomer. A similar situation has also been observed in other allylic alcohols derived from phenylalanine. ${ }^{35}$ From the chemical shift of this diagnostic proton it was thus possible to assign the $S, R$ and $S, S$ configurations to the major and minor isomers of alcohols 17a,b, respectively.

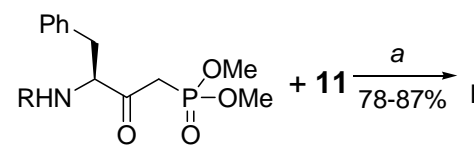

$15 a, b$<smiles>[R]NC(Cc1ccccc1)C(=O)/C=C/CNC(=O)COc1ccccc1</smiles>

$16 a, b$

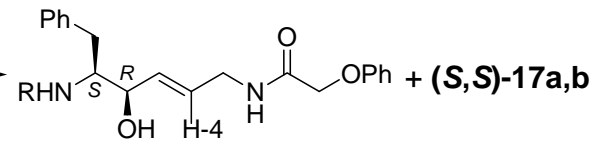

$(\mathrm{S}, \mathrm{R})-17 \mathrm{a}(\mathrm{R}=\mathrm{Poa})$

$\begin{aligned}(S, R)-17 b & (\mathrm{R}=\mathrm{Boc}) \\ \text { 17c } & (\mathrm{R}=\mathrm{PoaVal}) \\ & \square\end{aligned}$

$(S, R)-17 a \frac{d}{43 \%}$

8

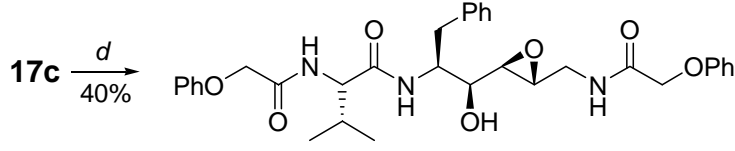

7

$a-\mathrm{K}_{2} \mathrm{CO}_{3}$, EtOH, $25{ }^{\circ} \mathrm{C}$; $b-\mathrm{NaBH}_{4}, \mathrm{MeOH}, 0{ }^{\circ} \mathrm{C}$; $c$ - TFA, $\mathrm{CH}_{2} \mathrm{Cl}_{2}$, then 13, $\mathrm{NEt}_{3}, \mathrm{CH}_{2} \mathrm{Cl}_{2}$, $25^{\circ} \mathrm{C} ; d$ - m-CPBA, $\mathrm{NaHCO}_{3}, \mathrm{CH}_{2} \mathrm{Cl}_{2}$.

Scheme 2. Synthesis of epoxyalcohol inhibitors.

The stereoselectivity of the reduction of enones $\mathbf{1 6}$ is consistent with chelation control by the metal or by the boron atom which might bind the carbamate nitrogen as suggested by Hoffmann et al. ${ }^{36}$ (Figure 4a). Alternatively, the same result could be explained with a Felkin-Anh model in which NHBoc is the medium group and benzyl is the large group ${ }^{32}$ (Figure 4b). Based on calculations of the volume of the two groups, it has been recently suggested that NHBoc is larger than benzyl; ${ }^{35}$ however, the bulky t-butyl group of NHBoc is four bonds away from the reaction center, to which it is connected by a linear, and relatively small, array of atoms. Thus the effectiveness of NHBoc in shielding the carbonyl from attack by the nucleophile may be overestimated by these calculations.

a

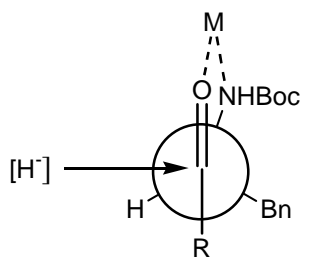

b

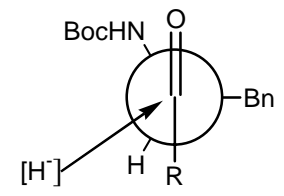

Figure 4. (a) Chelated and (b) Felkin-Anh models for borohydride reduction of aminoketones 16. 
Although the stereoselectivity of the reduction was not high, the diastereoisomers could be separated and obtained in pure form by column chromatography. The enantiomeric purity of alcohols $(\boldsymbol{S}, \boldsymbol{R})-\mathbf{1 7 a}, \mathbf{b}$ was assessed from the ${ }^{1} \mathrm{H}$ and ${ }^{13} \mathrm{C}$ NMR spectra of the corresponding Mosher's esters, in which only one set of signals was observed, indicating that no epimerization had occurred at the carbon atom adjacent to the carbonyl up to this stage in the synthesis. The $N$-Boc alcohol $(\boldsymbol{S}, \boldsymbol{R})-\mathbf{1 7 b}$ was deprotected and the phenoxyacetyl valine residue was introduced by reaction with the activated ester 13 giving alcohol 17c (Scheme 2). The final step is the epoxidation of allylic alcohols 17a,c to give the required epoxides 8 and 7. It is well known that peracid epoxidation of acyclic allylic alcohols is controlled by hydrogen bonding between the peracid and the hydroxy group of the substrate, leading to syn-epoxyalcohols ${ }^{37}$ and high syn stereoselectivity was found in the epoxidation of a series of allylic alcohols structurally related to $17 ;{ }^{32,38}$ on this basis the syn configuration shown in scheme 2 was assigned to epoxyalcohols 7 and 8 .

Preliminary evaluation of the biological activity. Epoxyalcohols $\mathbf{7}$ and $\mathbf{8}$ were preliminarly assayed for their ability to competitively inhibit recombinant, wild-type HIV-PR using a standard activity test with a fluorogenic substrate. ${ }^{28} \mathrm{IC}_{50}$ values for 7, 8, for the reference inhibitor PV and for epoxyalcohol 18, which was available from a previous investigation, ${ }^{32}$ are reported in Table 1. Data in the Table indicate that, on going from hexameric dihydroxyethylene inhibitor PV to tetrameric epoxyalcohol 7, inhibition potency decreases by three orders of magnitude. This is not surprising considering that $\mathbf{7}$ can only interact with four of the six protease's subsites involved in substrate binding, as discussed earlier in the section on design. On the other hand, the $\mathrm{IC}_{50}$ of 7 is comparable with that of other tetrameric inhibitors based on hydroxyethylene $^{29}$ and dihydroxyethylene ${ }^{28}$ isosteres, indicating that the more rigid trans-epoxide core of 7 does not interfere with binding to the protease's active site. Furthermore, very high affinity for the active site is not strictly required as 7 was designed as irreversible inhibitor. Removing the valine residue in $\mathrm{P} 2$ leads to a further increase in $\mathrm{IC}_{50}$, as observed for $\mathbf{8}$; an accurate evaluation of the inhibitory potency could not be obtained for this compound because of its poor solubility. Replacement of the Poa groups of $\mathbf{8}$ with Boc (in P2) and phenyl (P1'/P2') as in 18, considerably decreases the inhibitor's activity, confirming the ability of this residue to provide strong interactions with the protease. ${ }^{39}$

Table 1. $\mathrm{IC}_{50}$ values for HIV-PR inhibition

\begin{tabular}{ccc}
\hline Inhibitor & $\mathrm{IC}_{50}(\mu \mathrm{M})$ & $\mathrm{MW}$ \\
\hline $\mathbf{7}$ & 39 & 589.69 \\
$\mathbf{8}$ & $\sim 150$ & 490.56 \\
$\mathbf{1 8}$ & 570 & 383.49 \\
$\mathbf{P V}$ & $0.015^{\mathrm{a}}$ & 770.97 \\
\hline
\end{tabular}

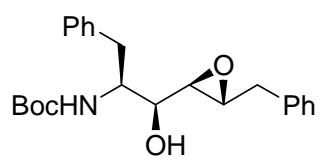

18

${ }^{\mathrm{a}}$ From ref. 28. 


\section{Conclusions}

A stereoselective approach originally developed for the synthesis of hydroxyethylene and dihydroxyethylene dipeptide isosteres has now been extended to the synthesis of HIV-PR inhibitors based on an epoxyalcohol core. Epoxyalcohols 7 and 8, designed to irreversibly inhibit HIV-PR by alkylating the catalytic carboxylate groups, were synthesized by this approach in approximately $10 \%$ yield overall, starting from phenylalanine. Both epoxyalcohols are recognized by HIV-PR leading to inhibition with $\mathrm{IC}_{50}$ values in the $\mu \mathrm{M}$ range. As recognition by the binding site is a prerequisite for selective reaction of the epoxide with the active site carboxylates, the ability of epoxyalcohols $\mathbf{7}$ and $\mathbf{8}$ to competitively inhibit HIV-PR makes them good candidates for selective irreversible inhibition of the enzyme. Epoxyalcohol 7 is particularly promising in this respect with an $\mathrm{IC}_{50}$ value comparable to that of other tetrameric inhibitors of HIV-PR and a molecular weight only slightly exceeding the limit of 500 postulated by Lipinski's "rule of five". ${ }^{40}$ A preliminary experiment indeed indicates that time-dependent inhibition is slowly taking place when HIV-PR is incubated with a given amount of epoxyalcohol 7.

\section{Experimental Section}

General Procedures. Moisture-sensitive reactions were carried out in oven-dried vessels under a positive argon pressure. Tetrahydrofuran was distilled from sodium-benzophenone prior to use. Flash column chromatography was performed on Merck silica gel 60 (230-400 mesh); Merck silica gel $60_{\mathrm{F} 254}$ coated plastic sheets $(0.25 \mathrm{~mm})$ were used for TLC and developed with iodine and/or permanganate. Melting points were determined with a Büchi 510 open capillary apparatus and are uncorrected. Optical rotations were measured at $589 \mathrm{~nm}$ in methanol with a Perkin-Elmer 261 polarimeter fitted with a $10 \mathrm{~cm}$ cell. IR spectra were recorded as Nujol mulls, unless otherwise noted, on a JASCO $200 \mathrm{FT} / \mathrm{IR}$ spectrophotometer. ${ }^{1} \mathrm{H}$ NMR spectra $(400 \mathrm{MHz})$ and ${ }^{13} \mathrm{C}$ NMR spectra $(100.4 \mathrm{MHz})$ were recorded for $\mathrm{CDCl}_{3}$ solutions containing tetramethylsilane as an internal standard, on a Jeol EX400 spectrometer. Electrospray ionization mass spectra (ESI-MS) were obtained on a SCIEX Perkin-Elmer API1 spectrometer and electron impact mass spectra (EI-MS) were obtained on a VG 7070 spectrometer at the interdepartmental centre for mass spectrometry of the University of Trieste. CHN analyses were obtained on a Carlo Erba 1106 elemental analyzer. Diastereomeric ratios were measured by NMR.

1-[(Phenoxyacetyl)oxy]pyrrolidine-2,5-dione (Poa-Osu, 9). Dicyclohexylcarbodiimide (DCC, $6.19 \mathrm{~g}, 30 \mathrm{mmol}$ ) was added in small portions, at $5{ }^{\circ} \mathrm{C}$, to a stirred solution of phenoxyacetic acid $(4.56 \mathrm{~g}, 300 \mathrm{mmol})$ and $\mathrm{N}$-hydroxysuccinimide (NHS, $3.45 \mathrm{~g}, 0.30 \mathrm{mmol})$ in $80 \mathrm{~mL}$ dry dioxane. The resulting mixture was stirred at room temperature for $2 \mathrm{~h}$, dicyclohexylurea was filtered off and the resulting solution was evaporated in vacuo. The residue was taken up in ethyl acetate and 
the mixture was filtered again to eliminate residual dicyclohexylurea. The solvent was then evaporated giving crude 9 (6.8 g, 91\%), m.p. 76-79 ${ }^{\circ} \mathrm{C}$ which was used without further purification. IR: $\mathrm{cm}^{-1} 1790,1730$ and $1700(\mathrm{C}=\mathrm{O})$. NMR: $\delta_{\mathrm{H}} 2.83(\mathrm{~s}, 4 \mathrm{H}), 4.97(\mathrm{~s}, 2 \mathrm{H}), 6.95(\mathrm{~d}$, $\left.2 \mathrm{H},{ }^{3} \mathrm{~J}=8.2 \mathrm{~Hz}\right), 7.03\left(\mathrm{t}, 1 \mathrm{H},{ }^{3} \mathrm{~J}=7.3 \mathrm{~Hz}\right), 7.32(\mathrm{~m}, 2 \mathrm{H}) ; \delta_{\mathrm{C}} 25.5,63.2,114.7,122.4,129.7$, 157.1, 164.6, 168.7 .

$N$-(2,2-Diethoxyethyl)-2-phenoxyacetamide (10). Poa-Osu (7, $5.63 \mathrm{~g}, 22.6 \mathrm{mmol})$ and 2,2diethoxyethylamine $(3.28 \mathrm{~mL}, 22.6 \mathrm{mmol})$ in $50 \mathrm{~mL}$ dry dichloromethane were kept at room temperature for $2 \mathrm{~h}$ upon which a clear solution was obtained. The solution was extracted with $10 \%$ aqueous $\mathrm{HCl}$, saturated aqueous bicarbonate, water and saturated brine in the order $(50 \mathrm{~mL}$ each), dried over anhydrous sodium sulfate and evaporated under reduced pressure giving the crude amide 10 (4.3 g, 71\%) which was used without purification. IR (film): $\mathrm{cm}^{-1} 3438(\mathrm{NH})$, $1673(\mathrm{CO})$. NMR: $\delta_{\mathrm{H}} 1.19\left(\mathrm{t}, 6 \mathrm{H},{ }^{3} J=7.0 \mathrm{~Hz}\right), 3.50(\mathrm{~m}, 4 \mathrm{H}), 3.69(\mathrm{~m}, 3 \mathrm{H}), 4.50(\mathrm{~s}, 2 \mathrm{H}), 6.84(\mathrm{~s}$, $1 \mathrm{H}, \mathrm{NH}), 6.91\left(\mathrm{~d}, 2 \mathrm{H},{ }^{3} \mathrm{~J}=8.4 \mathrm{~Hz}\right), 7.01\left(\mathrm{t}, 1 \mathrm{H},{ }^{3} \mathrm{~J}=7.3 \mathrm{~Hz}\right), 7.31(\mathrm{~m}, 2 \mathrm{H}) ; \delta_{\mathrm{C}} 15.2,41.3,62.9$, 67.2, 100.6, 114.5, 122.0, 129.6, 157.1, 168.2. ES-MS: m/z $268 \mathrm{MH}^{+}, 290[\mathrm{M}+\mathrm{Na}]^{+}$.

$\boldsymbol{N}$-(2-Oxoethyl)-2-phenoxyacetamide (11). A solution of the crude acetal 10 (2.20 g, 8.23 mmol) in $\mathrm{CH}_{2} \mathrm{Cl}_{2}(100 \mathrm{~mL})$ was vigorously stirred with $40 \mathrm{~mL}$ of $20 \%$ aqueous TFA until 10 could not be detected at the TLC (3-4 days). The organic phase was separated, extracted with saturated aqueous $\mathrm{NaHCO}_{3}$, water and sat. brine $(50 \mathrm{~mL}$ each) and dried over anhydrous $\mathrm{Na}_{2} \mathrm{SO}_{4}$. Evaporation of the solvent gave a residue which was triturated with ether giving the solid amide 11 (1.31 g, 82\%), m.p. 88-90 ${ }^{\circ} \mathrm{C}$. IR: $\mathrm{cm}^{-1} 3470$ (NH), 1740 (CO). NMR: $\delta_{\mathrm{H}} 4.28$ (d, $\left.2 \mathrm{H},{ }^{3} \mathrm{~J}=5.1 \mathrm{~Hz}\right), 4.56(\mathrm{~s}, 2 \mathrm{H}), 6.95\left(\mathrm{~d}, 2 \mathrm{H},{ }^{3} \mathrm{~J}=8.1 \mathrm{~Hz}\right), 7.04\left(\mathrm{t}, 1 \mathrm{H},{ }^{3} \mathrm{~J}=7.3 \mathrm{~Hz}\right), 7.30(\mathrm{~m}, 3 \mathrm{H}$, ArH and NH), $9.68(\mathrm{~s}, 1 \mathrm{H}) ; \delta_{\mathrm{C}} 49.5,67.1,114.6,122.2,129.7,157.0,168.7,195.7 . \mathrm{ES}-\mathrm{MS}: \mathrm{m} / \mathrm{z}$ $194 \mathrm{MH}^{+}$. Anal. Calcd. for $\mathrm{C}_{10} \mathrm{H}_{11} \mathrm{NO}_{3}$ (193.20): C 62.2; H 5.74; $\mathrm{N}$ 7.28. Found: C 62.4; H 5.79; N 7.29.

$\boldsymbol{N}$-(Phenoxyacetyl)-L-valine (12). L-valine $(2.1 \mathrm{~g}, 18 \mathrm{mmol})$ in $0.7 \mathrm{M}$ aqueous $\mathrm{NaOH}(25 \mathrm{~mL})$ was added dropwise to a solution of ester 9 in $50 \mathrm{~mL}$ dioxane and the reaction mixture was kept at room temperature for $1 \mathrm{~h}$. The solution was acidified to $\mathrm{pH} 2$ with conc. $\mathrm{HCl}$ and the acid 12 precipitated upon cooling $(3.31 \mathrm{~g}, 73 \%)$; the crude product was crystallized from ethyl acetate, m.p.128 - $130{ }^{\circ} \mathrm{C} .[\alpha]_{\mathrm{D}}{ }^{25}=-17\left(c\right.$ 0.2). IR: $\mathrm{cm}^{-1} 3372$ and $3345(\mathrm{NH}) ; 1712$ and $1625(\mathrm{C}=\mathrm{O})$. NMR: $\delta_{\mathrm{H}} 0.85\left(\mathrm{~d}, 3 \mathrm{H},{ }^{3} \mathrm{~J}=7.0 \mathrm{~Hz}\right), 0.89\left(\mathrm{~d}, 3 \mathrm{H},{ }^{3} \mathrm{~J}=6.8 \mathrm{~Hz}\right), 2.20(\mathrm{~m}, 1 \mathrm{H}), 4.51(\mathrm{~m}, 2 \mathrm{H}), 4.57$ $(\mathrm{m}, 1 \mathrm{H}), 6.88\left(\mathrm{~d}, 2 \mathrm{H},{ }^{3} \mathrm{~J}=8.6 \mathrm{~Hz}\right), 6.95\left(\mathrm{t}, 1 \mathrm{H},{ }^{3} \mathrm{~J}=7.3\right), 7.08\left(\mathrm{~d}, 1 \mathrm{H}, \mathrm{NH},{ }^{3} \mathrm{~J}=9.0 \mathrm{~Hz}\right), 7.22(\mathrm{~m}$, $2 \mathrm{H}), 9.82(\mathrm{~s}, 1 \mathrm{H}, \mathrm{COOH}) ; \delta_{\mathrm{C}} 17.5,18.9,31.0,56.7,67.1,114.8,122.2,129.7,157.0,169.1$, 175.0. EI-MS: m/z $251\left(\mathrm{M}^{+}, 28 \%\right), 206$ (28), 151 (60), 107 (98), 94 (100). Anal. Calcd. for $\mathrm{C}_{13} \mathrm{H}_{17} \mathrm{NO}_{4}$ (251.28): C 62.1; H 6.80; N 5.59. Found: C 62.6; H 7.01; N 5.77.

2,5-Dioxopyrrolidin-1-yl $\boldsymbol{N}$-(phenoxyacetyl)-L-valinate (13). The acid 12 (1.5 g, $5.97 \mathrm{mmol}$ ), NHS (0.69 g, $5.97 \mathrm{mmol})$ and DCC (1.23 g, $5.97 \mathrm{mmol})$, as described for the synthesis of 9, gave the crude ester $13(1.75 \mathrm{~g}, 84 \%)$ as a thick oil that was used without purification. IR (film): $\mathrm{cm}^{-1}$ 3450, $3350(\mathrm{NH})$; 1810, 1770, 1730, $1680(\mathrm{C}=\mathrm{O})$. NMR: $\delta_{\mathrm{H}} 1.02\left(\mathrm{~d}, 3 \mathrm{H},{ }^{3} \mathrm{~J}=5.8 \mathrm{~Hz}\right), 1.04(\mathrm{~d}$, $\left.3 \mathrm{H},{ }^{3} \mathrm{~J}=5.8 \mathrm{~Hz}\right), 2.38(\mathrm{~m}, 1 \mathrm{H}), 2.84(\mathrm{~m}, 4 \mathrm{H}), 4.57(\mathrm{~s}, 2 \mathrm{H}), 5.00\left(\mathrm{dd}, 1 \mathrm{H},{ }^{3} J=4.9,9.0 \mathrm{~Hz}\right), 6.95$ 
$\left(\mathrm{d}, 2 \mathrm{H},{ }^{3} \mathrm{~J}=7.9 \mathrm{~Hz}\right), 7.04(\mathrm{~m}, 2 \mathrm{H}, \mathrm{ArH}$ and $\mathrm{NH}), 7.3(\mathrm{~m}, 2 \mathrm{H}) ; \delta_{\mathrm{C}} 17.3,18.7,25.6,25.7,31.6$, $54.9,67.2,114.8,122.3,129.8,157.0,167.2,168.2,168.5$.

Methyl $\mathbf{N}$-(phenoxyacetyl)-L-phenylalaninate (14). A mixture of Poa-Osu 9 (6.00 g, $24 \mathrm{mmol})$, phenylalanine methyl ester hydrochloride $(5.18 \mathrm{~g}, 24 \mathrm{mmol})$ and triethylamine (3.34 $\mathrm{mL}, 24 \mathrm{mmol})$ in dry $\mathrm{CH}_{2} \mathrm{Cl}_{2}(100 \mathrm{~mL})$ was stirred at room temperature for $2 \mathrm{~h}$. Workup as described for 9 gave the ester 14, m.p. $53-55{ }^{\circ} \mathrm{C}(5.40 \mathrm{~g}, 72 \%)$. [ $\left.\alpha\right]_{\mathrm{D}}{ }^{25}-8.8$ (c 0.2$)$. IR: $\mathrm{cm}^{-1}$ $3400(\mathrm{NH}), 1730$ and $1710(\mathrm{C}=\mathrm{O})$. NMR: $\delta_{\mathrm{H}} 3.15(\mathrm{~d}, 2 \mathrm{H}), 3.70(\mathrm{~s}, 3 \mathrm{H}), 4.51(\mathrm{~m}, 2 \mathrm{H}), 4.97(\mathrm{~m}$, 1H) $6.87\left(\mathrm{~d}, 2 \mathrm{H},{ }^{3} \mathrm{~J}=8.0 \mathrm{~Hz}\right), 7.04(\mathrm{~m}, 4 \mathrm{H}, \mathrm{ArH}$ and $\mathrm{NH}), 7.29(\mathrm{~m}, 5 \mathrm{H}) ; \delta_{\mathrm{C}} 37.8,52.4,55.1$, 67.1, 114.6, 122.0, 127.1, 128.5, 129.1, 129.6, 135.4, 157.0, 167.9, 171.3. ES-MS: m/z 314 MH'; $331\left[\mathrm{M}+\mathrm{NH}_{4}\right]^{+}$. Anal. Calcd. for $\mathrm{C}_{18} \mathrm{H}_{19} \mathrm{NO}_{4}$ (315.37): C, 69.0; H, 6.11; N, 4.49. Found: C, 68.7; $\mathrm{H}, 6.20 ; \mathrm{N}, 4.78$.

Dimethyl \{(3S)-2-oxo-3-[(phenoxyacetyl)amino]-4-phenylbutyl\}phosphonate (15a). A $2.5 \mathrm{M}$ solution of $\mathrm{n}-\mathrm{BuLi}$ in hexane $(67 \mathrm{~mL}, 170 \mathrm{mmol})$ was added dropwise, under an argon atmosphere, at $-78{ }^{\circ} \mathrm{C}$, to dimethyl methylphosphonate $(18.1 \mathrm{~mL}, 170 \mathrm{mmol})$ in dry THF and the resulting solution was stirred at $-78{ }^{\circ} \mathrm{C}$ for $20 \mathrm{~min}$. A solution of ester 14 (10.5 g, $\left.33 \mathrm{mmol}\right)$ in dry THF $(66 \mathrm{~mL})$ was added and the reaction mixture was stirred for $2 \mathrm{~h}$ at $-78{ }^{\circ} \mathrm{C}$ under argon. The mixture was poured into $150 \mathrm{~mL}$ of a $20 \%$ aqueous solution of citric acid and extracted with ethyl acetate $(3 \times 70 \mathrm{~mL})$; the combined organic phases were extracted with sat. $\mathrm{NaHCO}_{3}$ and brine and dried over an. sodium sulfate. Evaporation of the solvent gave the product as an oil which was used for the next step without purification (11.49 $\mathrm{g}$, 86\%). IR (film): $\mathrm{cm}^{-1} 3300(\mathrm{NH}), 1720$ and $1670(\mathrm{C}=\mathrm{O}), 1245(\mathrm{P}=\mathrm{O})$. NMR: $\delta_{\mathrm{H}} 3.04\left(\mathrm{dd}, 1 \mathrm{H},{ }^{2} J=14.1\right.$ $\left.\mathrm{Hz},{ }^{3} \mathrm{~J}=8.4 \mathrm{~Hz}\right), 3.07\left(\mathrm{dd}, 1 \mathrm{H},{ }^{2} J_{\mathrm{H}-\mathrm{H}}=14.1 \mathrm{~Hz},{ }^{2} J_{\mathrm{H}-\mathrm{P}}=22.5 \mathrm{~Hz}\right), 3.21\left(\mathrm{dd}, 1 \mathrm{H},{ }^{2} \mathrm{~J}=14.1 \mathrm{~Hz},{ }^{3} \mathrm{~J}=\right.$ $5.5 \mathrm{~Hz}), 3.24\left(\mathrm{dd}, 1 \mathrm{H},{ }^{2} J_{\mathrm{H}-\mathrm{H}}=14.1 \mathrm{~Hz},{ }^{2} J_{\mathrm{H}-\mathrm{P}}=22.5 \mathrm{~Hz}\right), 3.72\left(\mathrm{~d}, 3 \mathrm{H},{ }^{3} J_{\mathrm{H}-\mathrm{P}}=11.4 \mathrm{~Hz}\right), 3.73(\mathrm{~d}$, $\left.3 \mathrm{H},{ }^{3} J_{\mathrm{H}-\mathrm{P}}=11.4 \mathrm{~Hz}\right), 4.41\left(\mathrm{~d}, 1 \mathrm{H},{ }^{2} J=15.0 \mathrm{~Hz}\right), 4.43\left(\mathrm{~d}, 1 \mathrm{H},{ }^{2} J=15.0 \mathrm{~Hz}\right), 4.99(\mathrm{~m}, 1 \mathrm{H}), 6.87$ $\left(\mathrm{d}, 2 \mathrm{H},{ }^{3} \mathrm{~J}=8.6 \mathrm{~Hz}\right), 7.01\left(\mathrm{t}, 1 \mathrm{H},{ }^{3} \mathrm{~J}=7.3 \mathrm{~Hz}\right), 7.12-7.32(\mathrm{~m}, 7 \mathrm{H}), 7.43\left(\mathrm{~d}, 1 \mathrm{H}, \mathrm{NH},{ }^{3} \mathrm{~J}=8.0\right.$ $\mathrm{Hz}) ; \quad \delta_{\mathrm{C}} 36.5,38.6\left(\mathrm{~d},{ }^{1} J_{\mathrm{C}-\mathrm{P}}=130.5 \mathrm{~Hz}\right), 53.0\left(\mathrm{~d},{ }^{2} J_{\mathrm{C}-\mathrm{P}}=6.4 \mathrm{~Hz}\right), 53.1\left(\mathrm{~d},{ }^{1} J_{\mathrm{C}-\mathrm{P}}=6.4 \mathrm{~Hz}\right), 59.2$, $67.0,114.5,122.0,127.0,128.6,129.2,129.7,135.8,157.1,168.3,199.9\left(\mathrm{~d},{ }^{2} J_{\mathrm{C}-\mathrm{P}}=6.4 \mathrm{~Hz}\right)$. ESMS: $\mathrm{m} / \mathrm{z} 406 \mathrm{MH}^{+}, 423\left[\mathrm{M}+\mathrm{NH}_{4}\right]^{+}$.

$\boldsymbol{N}, \boldsymbol{N}^{\prime}$-[(2E,5S)-4-Oxo-6-phenylhex-2-ene-1,5-diyl]bis(2-phenoxyacetamide) (16a). Oven dried potassium carbonate $(0.39 \mathrm{~g}, 2.8 \mathrm{mmol})$ was added in small portions, over $20 \mathrm{~min}$, to a solution of phosphonate 15a $(1.15 \mathrm{~g}, 2.8 \mathrm{mmol})$ and aldehyde $9(0.55 \mathrm{~g}, 2.8 \mathrm{mmol})$ in absolute ethanol $(25 \mathrm{~mL})$ and the suspension was stirred at room temperature for $25 \mathrm{~h}$. The solid was filtered off and the solution was neutralized with glacial acetic acid and evaporated to dryness under reduced pressure. The residue was partitioned between ethyl acetate $(25 \mathrm{~mL})$ and sat. sodium bicarbonate $(25 \mathrm{~mL})$ and the aqueous phase was extracted with ethyl acetate $(25 \mathrm{~mL})$. The combined organic phases were extracted with brine, dried over an. sodium sulfate and rotary evaporated giving the crude enone $(1.15 \mathrm{~g})$. Flash chromatography (ethyl acetate) gave pure 15a $(1.04 \mathrm{~g}, 78 \%)$. $[\alpha]_{\mathrm{D}}{ }^{25}-$ 7.8 (c 0.5). IR (film): $\mathrm{cm}^{-1} 3410(\mathrm{NH}), 1690,1685(\mathrm{C}=\mathrm{O}), 1660(\mathrm{C}=\mathrm{C}) . \mathrm{NMR}: \delta_{\mathrm{H}} 3.03(\mathrm{dd}, 1 \mathrm{H}$, $\left.{ }^{2} J=13.9 \mathrm{~Hz},{ }^{3} J=6.0 \mathrm{~Hz}\right), 3.08\left(\mathrm{dd}, 1 \mathrm{H},{ }^{2} J=13.9 \mathrm{~Hz},{ }^{3} \mathrm{~J}=6.9 \mathrm{~Hz}\right), 4.11(\mathrm{~m}, 2 \mathrm{H}), 4.46(\mathrm{~s}, 2 \mathrm{H})$, $4.54(\mathrm{~s}, 2 \mathrm{H}), 5.11(\mathrm{~m}, 1 \mathrm{H}), 6.13\left(\mathrm{~d}, 1 \mathrm{H},=\mathrm{CHCO},{ }^{3} \mathrm{~J}=15.9 \mathrm{~Hz}\right), 6.77-7.36(\mathrm{~m}, 18 \mathrm{H}) ; \delta_{\mathrm{C}} 37.7$, 
39.7, 56.8, 67.1, 114.5, 122.1, 126.6, 127.0, 128.5, 129.3, 129.7, 129.8, 135.4, 143.9, 157.0, 167.9, 168.3, 195.8. ES-MS: m/z $473 \mathrm{MH}^{+}, 495[\mathrm{M}+\mathrm{Na}]^{+}$.

tert-Butyl \{(1S,3E)-1-benzyl-2-oxo-5-[(phenoxyacetyl)amino]pent-3-en-1-yl\}carbamate (16b). Phosphonate $\mathbf{1 5 b}^{32}(1.15 \mathrm{~g}, 3.1 \mathrm{mmol})$ and aldehyde $\mathbf{1 1}(0.60 \mathrm{~g}, 3.1 \mathrm{mmol})$, as described for 16a, gave 16b (87\% after chromatography), m.p. $98-100{ }^{\circ} \mathrm{C}$ (from diisopropyl ether). $[\alpha]_{\mathrm{D}}{ }^{25}=-3.3$ (c 0.3). IR: $\mathrm{cm}^{-1} 3415$ and $3340(\mathrm{NH}), 1690(\mathrm{C}=\mathrm{O}), 1660(\mathrm{C}=\mathrm{C}) . \mathrm{NMR}: \delta_{\mathrm{H}} 1.33(\mathrm{~s}, 9 \mathrm{H}), 2.87$ $\left(\mathrm{dd}, 1 \mathrm{H},{ }^{2} \mathrm{~J}=13.6 \mathrm{~Hz},{ }^{3} \mathrm{~J}=5.7 \mathrm{~Hz}\right), 2.97\left(\mathrm{dd}, 1 \mathrm{H},{ }^{2} \mathrm{~J}=13.6 \mathrm{~Hz},{ }^{3} \mathrm{~J}=6.7 \mathrm{~Hz}\right), 4.04(\mathrm{~s}, 2 \mathrm{H}), 4.45$ $(\mathrm{s}, 2 \mathrm{H}), 4.65(\mathrm{~m}, 1 \mathrm{H}), 5.15\left(\mathrm{~d}, 1 \mathrm{H}, \mathrm{NH},{ }^{3} \mathrm{~J}=6.8 \mathrm{~Hz}\right), 6.06\left(\mathrm{~d}, 1 \mathrm{H},=\mathrm{C} \underline{\mathrm{HCO}},{ }^{3} J=15.7 \mathrm{~Hz}\right), 6.66-$ $7.29(\mathrm{~m}, 12 \mathrm{H}) ; \delta_{\mathrm{C}} 28.1,37.9,39.6,58.6,67.1,79.7,114.5,122.2,126.7,128.3,129.3,129.6$, 129.7, 135.9, 143.3 , 155.0, 157.0, 168.2, 196.1. ES-MS: m/z $439 \mathrm{MH}^{+}, 462[\mathrm{M}+\mathrm{Na}]^{+}, 339[\mathrm{MH}-$ Boc] $]^{+}$. Anal. Calcd. for $\mathrm{C}_{25} \mathrm{H}_{30} \mathrm{~N}_{2} \mathrm{O}_{5}$ (438.52): C, 68.4; H, 6.89; N, 6.41. Found: C, 67.9; H, 6.70; $\mathrm{N}, 6.28$.

$N, N^{\prime}-[(2 E, 4 R, 5 S)-4-H y d r o x y-6-p h e n y l h e x-2-e n e-1,5-d i y l] b i s(2-p h e n o x y a c e t a m i d e) \quad(17 a)$. $\mathrm{NaBH}_{4}(0.032 \mathrm{~g}, 0.85 \mathrm{mmol})$ was added in small portions, at $0{ }^{\circ} \mathrm{C}$, to a well stirred solution of enone 16a in $\mathrm{MeOH}(15 \mathrm{~mL})$ and stirring was continued for $45 \mathrm{~min}$ at the same temperature. The mixture was neutralized with glacial acetic acid, the solvent was removed under reduced pressure and the residue was partitioned between ethyl acetate $(40 \mathrm{~mL})$ and saturated aqueous $\mathrm{NaHCO}_{3}$ $(40 \mathrm{~mL})$. The aqueous phase was extracted with ethyl acetate $(40 \mathrm{~mL})$ and the combined organic phases were extracted with sat. brine and dried over an. sodium sulfate. Evaporation of the solvent under reduced pressure gave a $3: 1$ mixture of $(4 R, 5 S)$ and $(4 S, 5 S)$ diastereoisomers $(0.39 \mathrm{~g}, 97 \%)$ which were separated by flash chromatography (eluant: ethyl acetate/diethyl ether 1:1). (4R,5S)-17a. m.p. $11{ }^{\circ} \mathrm{C}$ (from diisopropyl ether). $[\alpha]_{\mathrm{D}}{ }^{25}=-37.3$ (c 0.3 ). IR: $\mathrm{cm}^{-1} 3425$ $(\mathrm{NH}, \mathrm{OH}), 1700,1680(\mathrm{C}=\mathrm{O}), 1650(\mathrm{C}=\mathrm{C}) . \mathrm{NMR}: \delta_{\mathrm{H}} 2.78\left(\mathrm{dd}, 1 \mathrm{H},{ }^{2} \mathrm{~J}=14.3 \mathrm{~Hz},{ }^{3} \mathrm{~J}=9.0 \mathrm{~Hz}\right)$, $2.97\left(\mathrm{dd}, 1 \mathrm{H},{ }^{2} \mathrm{~J}=14.3 \mathrm{~Hz},{ }^{3} \mathrm{~J}=5.2 \mathrm{~Hz}\right), 3.46(\mathrm{bs}, 1 \mathrm{H}, \mathrm{OH}), 3.95(\mathrm{t}, 2 \mathrm{H}), 4.23(\mathrm{~m}, 1 \mathrm{H}), 4.31(\mathrm{~m}$, $1 \mathrm{H}), 4.33\left(\mathrm{~d}, 1 \mathrm{H},{ }^{2} \mathrm{~J}=15.2 \mathrm{~Hz}\right), 4.43\left(\mathrm{~d}, 1 \mathrm{H},{ }^{2} \mathrm{~J}=15.2 \mathrm{~Hz}\right), 4.47(\mathrm{~s}, 2 \mathrm{H}), 5.65\left(\mathrm{dd}, 1 \mathrm{H},{ }^{3} \mathrm{~J}=5.7\right.$, $15.6 \mathrm{~Hz}), 5.75\left(\mathrm{dt}, 1 \mathrm{H},{ }^{3} \mathrm{~J}=5.4,15.6 \mathrm{~Hz}\right), 6.65\left(\mathrm{~d}, \mathrm{NH},{ }^{3} \mathrm{~J}=8.0 \mathrm{~Hz}\right), 6.72(\mathrm{~m}, 1 \mathrm{H}, \mathrm{NH}), 6.79$ (d, $2 \mathrm{H}), 6.91(\mathrm{~d}, 2 \mathrm{H}), 7.01(\mathrm{~m}, 2 \mathrm{H}), 7.13(\mathrm{~d}, 2 \mathrm{H}), 7.17-7.35(\mathrm{~m}, 7 \mathrm{H}) ; \delta_{\mathrm{C}} 35.6,40.2,55.2,67.2,73.4$, 114.6, 114.65, 122.1, 126.7, 128.4, 128.6, 129.1, 129.7, 129.8, 131.1, 137.1, 157.0, 168.1, 169.0. EI-MS: m/z $456\left([\mathrm{M}-\mathrm{H} 2 \mathrm{O}]^{+}\right.$1\%)], 107 (65), 94 (62), 77 (100). Anal. Calcd. for $\mathrm{C}_{28} \mathrm{H}_{30} \mathrm{~N}_{2} \mathrm{O}_{5}$ (474.56): C, 70.9; H, 6.37; N, 5.93. Found: C, 70.6; H, 6.22; N, 5.92. (4S,5S)-17a: m. p. 128$130{ }^{\circ} \mathrm{C}$ (from diisopropyl ether). $[\alpha]_{\mathrm{D}}{ }^{25}=-50.6$ (c 0.34). IR: $\mathrm{cm}^{-1} 3390(\mathrm{NH}, \mathrm{OH}), 1700,1680$ $(\mathrm{C}=\mathrm{O}), 1650(\mathrm{C}=\mathrm{C})$. NMR: $\delta_{\mathrm{H}} 2.88\left(\mathrm{dd}, 1 \mathrm{H},{ }^{2} \mathrm{~J}=13.5 \mathrm{~Hz},{ }^{3} J=7.2 \mathrm{~Hz}\right), 2.97\left(\mathrm{dd}, 1 \mathrm{H},{ }^{2} J=13.5\right.$ $\left.\mathrm{Hz},{ }^{3} J=5.0 \mathrm{~Hz}\right), 2.90$ (bs, 1H, OH), $3.87(\mathrm{~m}, 2 \mathrm{H}), 4.16(\mathrm{~m}, 2 \mathrm{H}), 4.31(\mathrm{~m}, 1 \mathrm{H}), 4.37\left(\mathrm{~d}, 1 \mathrm{H},{ }^{2} J=\right.$ $14.7 \mathrm{~Hz}), 4.42(\mathrm{~s}, 2 \mathrm{H}), 4.43\left(\mathrm{~d}, 1 \mathrm{H},{ }^{2} \mathrm{~J}=14.7 \mathrm{~Hz}\right), 5.56\left(\mathrm{dd}, 1 \mathrm{H},{ }^{3} \mathrm{~J}=5.1,15.6 \mathrm{~Hz}\right), 5.68(\mathrm{dt}, 1 \mathrm{H}$, $\left.{ }^{3} J=5.5,15.6 \mathrm{~Hz}\right), 6.65\left(\mathrm{~d}, \mathrm{NH},{ }^{3} J=8.0 \mathrm{~Hz}\right), 6.71(\mathrm{~m}, 1 \mathrm{H}, \mathrm{NH}), 6.8-6,92(\mathrm{~m}, 5 \mathrm{H}), 7.15-7.35(\mathrm{~m}$, $9 \mathrm{H}) ; \delta_{\mathrm{C}} 37.6,40.1,54.6,67.1,67.3,71.3,114.6,114.7,122.1,126.6,127.5,128.5,129.2,129.7$, 129.8, 132.5, 137.6, 157.0, 157.2, 168.1, 168.6. EI-MS: m/z $456\left([\mathrm{M}-\mathrm{H} 2 \mathrm{O}]^{+}\right.$2\%), 149 (100), 107 (28), 94 (40), 77 (50). Anal. Calcd. for $\mathrm{C}_{28} \mathrm{H}_{30} \mathrm{~N}_{2} \mathrm{O}_{5}$ (474.56): C, 70.9; H, 6.37; N, 5.93. Found: C, 71.2; H, 6.30; N, 5.92. 
tert-Butyl $\{(1 S, 2 R, 3 E)-1-b e n z y l-2-h y d r o x y-5-[(p h e n o x y a c e t y l) a m i n o] p e n t-3-e n-1-y l\}$ carbamate (17b). Borohydride reduction of enone $\mathbf{1 6 b}(0.59 \mathrm{~g}, 1.3 \mathrm{mmol})$ gave a $3: 1$ mixture of $(1 S, 2 R)$ and $(1 S, 2 S)$ diastereoisomers $(0.53 \mathrm{~g}, 92 \%)$ which were separated by flash chromatography (eluant: ether). (1S,2R)-17b. m.p. $129^{\circ} \mathrm{C}$ (from diisopropyl ether). $[\alpha]_{\mathrm{D}}^{25}=-41$ (c 0.29). IR: $\mathrm{cm}^{-}$ $13470(\mathrm{NH}, \mathrm{OH}), 1680(\mathrm{C}=\mathrm{O}), 1645(\mathrm{C}=\mathrm{C}) . \mathrm{NMR}: \delta_{\mathrm{H}} 1.28(\mathrm{~s}, 9 \mathrm{H}), 2.64(\mathrm{~m}, 1 \mathrm{H}), 2.73(\mathrm{dd}, 1 \mathrm{H}$, $\left.{ }^{2} J=14.2 \mathrm{~Hz},{ }^{3} J=5.2 \mathrm{~Hz}\right), 3.88(\mathrm{~m}, 2 \mathrm{H}),(\mathrm{s}, 2 \mathrm{H}), 4.13$ (broad, $\left.1 \mathrm{H}, \mathrm{OH}\right), 4.40(\mathrm{~m}, 1 \mathrm{H}), 4.42$ (s, 2H), $4.70\left(\mathrm{~d}, 1 \mathrm{H}, \mathrm{NH},{ }^{3} J=8.2 \mathrm{~Hz}\right), 5.59\left(\mathrm{dd}, 1 \mathrm{H},{ }^{3} J=5.7,15.5 \mathrm{~Hz}\right), 5.75\left(\mathrm{dt}, 1 \mathrm{H},{ }^{3} J=5.5,15.5\right.$ $\mathrm{Hz}), 6.69(\mathrm{~m}, 1 \mathrm{H}, \mathrm{N} \underline{\mathrm{H}}), 6.84(\mathrm{~d}, 2 \mathrm{H}), 6.94(\mathrm{t}, 1 \mathrm{H}), 7.05-7.25(\mathrm{~m}, 7 \mathrm{H}) ; \delta_{\mathrm{C}} 28.7,35.9,40.3,56.4$, 67.1, 73.8, 79.7, 114.6, 122.1, 126.3, 127.9, 128.4, 129.2, 129.7, 131.4, 137.7, 156.4, 157.0, 168.2. EI-MS: m/z 365 (20\%), 274 (100), 151 (55). Anal. Calcd. for $\mathrm{C}_{25} \mathrm{H}_{32} \mathrm{~N}_{2} \mathrm{O}_{5}$ (440.54): C, 68.1; H, 7.32; N, 6.38. Found: C, 68.1; H, 7.39; N, 6.46. (1S,2S)-17b: m.p $99-101{ }^{\circ} \mathrm{C}$ (from diisopropyl ether). IR: $\mathrm{cm}^{-1} 3326(\mathrm{NH}, \mathrm{OH}), 1676(\mathrm{C}=\mathrm{O}), 1650(\mathrm{C}=\mathrm{C}) . \mathrm{NMR}: \delta_{\mathrm{H}} 1.40(\mathrm{~s}, 9 \mathrm{H})$, 2.75-3.05 (m, 2H), $3.96(\mathrm{~m}, 2 \mathrm{H}), 4.10$ (broad, 1H, O프), $4.45(\mathrm{~m}, 1 \mathrm{H}), 4.50(\mathrm{~s}, 2 \mathrm{H}), 4.94(\mathrm{~d}, 1 \mathrm{H}$, $\left.\mathrm{NH},{ }^{3} J=9.1 \mathrm{~Hz}\right), 5.70(\mathrm{~m}, 2 \mathrm{H}), 6.75-7.35(\mathrm{~m}, 11 \mathrm{H}) ; \delta_{\mathrm{C}} 28.2,36.1,40.7,56.6,67.2,74.3,79.7$, $114.9,121.8,126.8,127.8,128.4,129.1,129.7,131.6,137.9,156.8,157.0,168.1 . \mathrm{ES}-\mathrm{MS}: \mathrm{m} / \mathrm{z}$ $441 \mathrm{MH}^{+}, 458\left[\mathrm{M}+\mathrm{NH}_{4}\right]^{+}, 341[\mathrm{MH}-\mathrm{Boc}]^{+}$. Anal. Calcd. for $\mathrm{C}_{25} \mathrm{H}_{32} \mathrm{~N}_{2} \mathrm{O}_{5}$ (440.54): C, 68.1; H, 7.32; N, 6.38. Found: C, 68.3; H, 7.45; N, 6.33.

$N^{2}$-(Phenoxyacetyl)- $N^{1}$-[(1S,2R,3E)-1-benzyl-2-hydroxy-5-(phenoxyacetylamino)pent-3-en1-yl]-L-valinamide (17c). N-Boc protected alcohol (1S,2R)-17b (405 mg, $0.92 \mathrm{mmol})$ in $2 \mathrm{~mL}$ dichloromethane was deprotected with trifluoroacetic acid $(1 \mathrm{~mL})$ for $10 \mathrm{~min}$. The solvent was evaporated under reduced pressure and the residue was partitioned between dichloromethane (10 $\mathrm{mL})$ and sat. $\mathrm{NaHCO}_{3}(10 \mathrm{~mL})$. The organic phase was extracted with sat. brine and dried over an. sodium sulfate. To the solution containing the deprotected amine were added the activated ester $13(321 \mathrm{mg}, 0.92 \mathrm{mmol})$ and triethylamine $(132 \mu \mathrm{L}, 0.92 \mathrm{mmol})$ and the reaction mixture was kept at room temperature for $12 \mathrm{~h}$. The solution was extracted with sat. $\mathrm{NaHCO}_{3}$ and brine, dried over an. sodium sulfate and the solvent was evaporated under reduced pressure. The residue was triturated with ethyl acetate giving the alcohol 17c $(235 \mathrm{mg}, 45 \%)$; m.p. $177-179{ }^{\circ} \mathrm{C}$ (from ethyl acetate). $[\alpha]_{\mathrm{D}}^{25}=-30.2$ (c 0.2). IR: $\mathrm{cm}^{-1} 3330(\mathrm{NH}, \mathrm{OH}), 1665(\mathrm{C}=\mathrm{O}), 1640(\mathrm{C}=\mathrm{C})$. NMR: $\quad \delta_{\mathrm{H}} 0.64\left(\mathrm{~d}, 3 \mathrm{H},{ }^{3} \mathrm{~J}=6.1 \mathrm{~Hz}\right), 0.77\left(\mathrm{~d}, 3 \mathrm{H},{ }^{3} \mathrm{~J}=6.1 \mathrm{~Hz}\right), 1.84(\mathrm{broad}, 1 \mathrm{H}, \mathrm{OH}), 2.02$ $(\mathrm{m}, 1 \mathrm{H}), 2.60\left(\mathrm{dd}, 1 \mathrm{H},{ }^{2} \mathrm{~J}=13.6 \mathrm{~Hz},{ }^{3} \mathrm{~J}=9.7 \mathrm{~Hz}\right), 2.80\left(\mathrm{dd}, 1 \mathrm{H},{ }^{2} \mathrm{~J}=13.6 \mathrm{~Hz},{ }^{3} \mathrm{~J}=5 \mathrm{~Hz}\right), 3.91$ (s, 2H), 4.05-4.30 (m, 3H), $4.32\left(\mathrm{~d}, 1 \mathrm{H},{ }^{3} \mathrm{~J}=15.0 \mathrm{~Hz}\right), 4.40\left(\mathrm{~d}, 1 \mathrm{H},{ }^{3} \mathrm{~J}=15.0 \mathrm{~Hz}\right), 4.44(\mathrm{~s}, 2 \mathrm{H}), 5.59$ $\left(\mathrm{dd}, 1 \mathrm{H},{ }^{3} J=4.6,15.2 \mathrm{~Hz}\right), 5.73\left(\mathrm{dt}, 1 \mathrm{H},{ }^{3} J=5.0,15.4 \mathrm{~Hz}\right), 6.34(\mathrm{~m}, 1 \mathrm{H}), 6.7-7.3(\mathrm{~m}, 17 \mathrm{H}) ; \delta_{\mathrm{C}}$ 17.6, 19.3, 30.0, 35.7, 40.4, 55.5, 58.3, 66.9, 67.2, 76.7, 114.6, 122.1, 122.2, 126.6, 127.2, 128.4, $129.0,129.2,129.7,129.8,130.8,137.4,157.0,157.1,168.4,168.6,171.3$. Anal. Calcd. for $\mathrm{C}_{33} \mathrm{H}_{39} \mathrm{~N}_{3} \mathrm{O}_{6}$ (573.70): C, 69.1; H, 6.85; N, 7.35. Found: C, 69.0; H, 6.90; N, 7.29.

2,3-Anhydro-1,5,6-trideoxy-1,5-bis[(phenoxyacetyl)amino]-6-phenyl-L-glucitol (8). A solution of $60 \% \mathrm{~m}$-CPBA $(50 \mathrm{mg}, 0.18 \mathrm{mmol})$ in dry $\mathrm{CH}_{2} \mathrm{Cl}_{2}(5 \mathrm{~mL})$ was added to a stirred suspension of sodium hydrogen carbonate $(15 \mathrm{mg}, 0.18 \mathrm{mmol})$ in dichloromethane $(5 \mathrm{~mL})$ in which the alkene (1S,2R)-17a (70 $\mathrm{mg}, 0.15 \mathrm{mmol})$ had been previously dissolved. The reaction mixture was stirred at room temperature for $24 \mathrm{~h}$, extracted with $5 \%$ aqueous sodium 
metabisulfite, sat. bicarbonate and brine $(5 \mathrm{~mL}$ each), and dried over an. sodium sulfate. The solvent was evaporated under reduced pressure giving the crude epoxide 8 (30 mg, 43\%); m.p. $185{ }^{\circ} \mathrm{C}$ (dec., from ethyl acetate). $[\alpha]_{\mathrm{D}}^{25}=-17.5$ (c 0.24). IR: $\mathrm{cm}^{-1} 3290(\mathrm{NH}, \mathrm{OH}), 1648(\mathrm{C}=\mathrm{O})$. NMR: $\delta_{\mathrm{H}} 1.7$ (broad, 1H, O파), $2.84(\mathrm{~m}, 1 \mathrm{H}), 2.97(\mathrm{~m}, 2 \mathrm{H}), 3.08(\mathrm{~m}, 1 \mathrm{H}), 3.45-3.65(\mathrm{~m}, 3 \mathrm{H})$, $4.36\left(\mathrm{~d}, 1 \mathrm{H},{ }^{2} \mathrm{~J}=15.0 \mathrm{~Hz}\right), 4.41(\mathrm{~m}, 1 \mathrm{H}), 4.47(\mathrm{~s}, 2 \mathrm{H}), 4.49\left(\mathrm{~d}, 1 \mathrm{H},{ }^{2} \mathrm{~J}=15.0 \mathrm{~Hz}\right), 6.7-7.3(\mathrm{~m}$, $17 \mathrm{H}) ; \delta_{\mathrm{C}} 35.7,39.4,53.1,54.1,57.8,67.0,67.1,71.8,114.5,114.6,122.1,122.2,126.8,128.7$, 129.3, 129.7, 129.8, 136.6, 157.0, 157.1, 168.8, 168.9. ES-MS: m/z $491 \mathrm{MH}^{+}, 513[\mathrm{M}+\mathrm{Na}]^{+}$. Anal. Calcd. for $\mathrm{C}_{28} \mathrm{H}_{30} \mathrm{~N}_{2} \mathrm{O}_{6}$ (490.55): C, 68.6; H, 6.16; N, 5.71. Found: C, 68.2; H, 6.26; N, 5.95 .

\section{2,3-Anhydro-1,5,6-trideoxy-1-[(phenoxyacetyl)amino]-5-\{[N-(phenoxyacetyl)-L-valyl]} amino\}-6-phenyl-L-glucitol (7). Epoxidation of 17c (110 mg, $0.19 \mathrm{mmol})$ with $60 \% \mathrm{~m}$-CPBA (66 mg, $0.23 \mathrm{mmol}$ ) and $\mathrm{NaHCO}_{3}(19 \mathrm{mg}, 0.23 \mathrm{mmol})$ gave 7 (45 mg, 40\%): m.p. $145{ }^{\circ} \mathrm{C}$ (dec., ethyl acetate). $[\alpha]_{\mathrm{D}}^{25}=-16.9\left(c\right.$ 0.26). IR: $\mathrm{cm}^{-1} 3280(\mathrm{NH}, \mathrm{OH}), 1650(\mathrm{C}=\mathrm{O}) . \mathrm{NMR}: \delta_{\mathrm{H}} 0.61(\mathrm{~d}$, $\left.3 \mathrm{H},{ }^{3} \mathrm{~J}=6.8 \mathrm{~Hz}\right), 0.74\left(\mathrm{~d}, 3 \mathrm{H},{ }^{3} \mathrm{~J}=6.8 \mathrm{~Hz}\right), 1.68(\mathrm{~s}, 1 \mathrm{H}, \mathrm{OH}), 2.07(\mathrm{~m}, 1 \mathrm{H}), 2.65-2.95(\mathrm{~m}, 3 \mathrm{H})$, $3.05(\mathrm{~m}, 1 \mathrm{H}), 3.4-3.5(\mathrm{~m}, 3 \mathrm{H}), 4.11(\mathrm{~m}, 1 \mathrm{H}), 4.4(\mathrm{~m}, 5 \mathrm{H}), 6.37\left(\mathrm{~d}, 1 \mathrm{H}, \mathrm{N} \underline{\mathrm{H}},{ }^{3} J=6.8 \mathrm{~Hz}\right), 6.8-7.3$ $(\mathrm{m}, 17 \mathrm{H}) ; \delta_{\mathrm{C}} 17.4,19.3,29.8,36.0,39.4,53.7,54.2,57.6,58.6,67.1,67.2,71.9,114.6,114.7$, 122.2, 122.3, 126.7, 128.6, 129.0, 129.8, 129.9, 137.1, 157.0, 157.1, 168.8, 168.9, 170.9. ES-MS: $\mathrm{m} / \mathrm{z} 590 \mathrm{MH}^{+}, 612[\mathrm{M}+\mathrm{Na}]^{+}$. Anal. Calcd. for $\mathrm{C}_{33} \mathrm{H}_{39} \mathrm{~N}_{3} \mathrm{O}_{7}$ (589.69): C, 67.2; H, 6.67; N, 7.13. Found: C, 67.4; H, 6.28; N, 7.15.

Enzyme assays. Recombinant HIV-1 protease was purchased from Bioczech (Prague, Czech Republic). The fluorogenic substrate Abz-Thr-Ile-Nle-Phe $\left(\mathrm{NO}_{2}\right)-\mathrm{Gln}-\mathrm{Arg}-\mathrm{NH}_{2}$ was from Bachem (Bubendorf, $\mathrm{CH}$ ). The extent of inhibition of the activity of HIV-1 PR was evaluated as previously reported for compounds based on a dihydroxyethylene module. ${ }^{28}$ In particular, assays were performed at $\mathrm{pH} 5.5$ and $25^{\circ} \mathrm{C}$ in $400 \mathrm{mM} \mathrm{NaCl}, 1 \mathrm{mM}$ EDTA, $1 \mathrm{mM}$ DTT, $100 \mathrm{mM}$ MES$\mathrm{NaOH}$ buffer, in the presence of $30 \mu \mathrm{M}$ fluorogenic substrate Abz-Thr-Ile-Nle-Phe(NO) ${ }_{2}-\mathrm{Gln}$ Arg- $\mathrm{NH}_{2}$ and $10 \mathrm{nM}$ HIV-PR.

\section{Acknowledgements}

Support by Istituto Superiore di Sanità (National Research Programme on Aids) and FIRB (Programma Strategico Post Genoma, grant RBNE017F8N) is gratefully acknowledged. We thank Dr. Fabio Hollan for the massa spectra.

\section{References}

1. Hoffmann, C.; Kamps, B. S., Eds. HIV Medicine 2003; Flying Publisher: Paris, 2003 (www.HIVMedicine.com).

2. Richman, D.D. Nature 2001, 410, 995. 
3. Tomasselli, A. G.; Heinrikson, R. L. Biochim. Biophys. Acta 2000, 1477, 189.

4. Moyle, G.; Gazzard, B. Drugs 1996, 51, 701.

5. www.niaid.nih.gov/daids/dtpdb/fdadrug.htm

6. Navia, M. A.; Fitzgerald, M. D. P.; Mckeever, B. M.; Leu, C.-T.; Heimbach, J. C.; Herber, W. K.; Sigal, I. S.; Darke, P. L.; Spronger, J. P. Nature 1989, 337, 615.

7. Wlodawer, A.; Miller, M.; Jaskolski, M.; Sathyanarayana, B. K.; Baldwin, E.; Weber, I. T.; Selk, L. M.; Clawson, L.; Schneider, J.; Kent, S. B. H. Science 1989, 245, 616.

8. Wlodawer, A.; Gustchina, A. Biochim. Biophys. Acta 2000, 1477, 16.

9. Brik, A.; Wong, C.-H. Org. Biomol. Chem. 2003, 1, 5.

10. Ghosh, A. K.; Bilcer, G.; Schiltz, G. Synthesis 2001, 2203.

11. Lebon, F.; Ledecq, M. Curr. Med. Chem. 2000, 7, 455.

12. Leung, D.; Abbenante, G.; Fairlie, D. P. J. Med. Chem. 2000, 43, 305.

13. Babine, R. E.; Bender, S. L. Chem. Rev. 1997, 97, 1359.

14. Kempf, D. J.; Sham, H. L. Curr. Pharm. Design 1996, 2, 225.

15. Meek, T. D.; Dayton, B. D.; Metcalf, B. W.; Dreyer, G. B.; Strickler, J. E.; Gorniak, J. G.; Rosenberg, M.; Moore, M. L.; Magaard, V. W.; Debouck, C. Proc. Natl. Acad. Sci. USA 1989, 86, 1841.

16. Salto, R.; Babé, L. M.; Li, J.; Rosé, J. R.; Yu, Z.; Burlingame, A.; De Voss, J. J.; Sui, Z.; Ortiz de Montellano, P.; Craik, C. S. J. Biol. Chem. 1994, 269, 10691.

17. Said, B.; Matsumoto, D. C.; Hamade, A. K.; Shank, R. C. Biochem. Biophys. Res. Commun. 1999, 261, 844.

18. De Voss, J. J.; Sui, Z.; DeCamp D. L.; Salto, R.; Babé, L. M.; Craik, C. S.; Ortiz de Montellano, P. R. J. Med. Chem. 1994, 37, 665.

19. Yu, Z.; Caldera, P.; McPhee, F.; De Voss, J. J.; Jones, P. R.; Burlingame, A. L.; Kuntz, I. D.; Craik, C. S.; Ortiz de Montellano, P. R. J. Am. Chem. Soc. 1996, 118, 5846.

20. Grant, S. K.; Moore, M. L. ; Fakhouri, S. A.; Tomaszek, T. A.; Meek, T. D. Bioorg. Med. Chem. Lett. 1996, 6, 589.

21. Abell, A. D.; Hoult, D. A.; Bergman, D. A.; Fairlie, D. P. Bioorg. Med. Chem. Lett. 1997, 7, 2853.

22. Choy, N.; Choi, H.; Jung, W. H.; Kim, C. R.; Yoon, H.; Kim, S. C.; Lee, T. G.; Koh, J. S. Bioorg. Med. Chem. Lett. 1997, 7, 2635.

23. Lee, C. S.; Choy, N.; Park, C.; Choi, H.; Son, Y. C.; Kim, S.; Ok, J. H.; Yoon, H.; Kim, S. C. Bioorg. Med. Chem. Lett. 1996, 6, 589.

24. Park, C.; Koh, J. S.; Son, Y. C.; Choi, H.; Lee, C. S.; Choy, N.; Moon, K. Y.; Jung, W. H.; Kim, S. C.; Yoon, H. Bioorg. Med. Chem. Lett. 1995, 5, 1843.

25. Caldera, P. S.; Yu, Z.; Knegtel, R. M. A.; McPhee, F.; Burlingame, A. L.; Craik, C. S.; Kuntz, I. D.; Ortiz de Montellano, P. R. Bioorg. Med. Chem. 1997, 5, 2019.

26. Mavri, J. Int. J. Quantum Chem. 1998, 69, 753.

27. Tossi, A.; Antcheva, N.; Benedetti F.; Norbedo S.; Miertus, S.; Romeo, D. Prot. Peptide Lett. 1999, 6, 145. 
28. Tossi, A.; Bonin, I.; Antcheva, N.; Norbedo S.; Benedetti F.; Miertus, S.; Nair, A. C.; Maliar, T.; Dal Bello, F.; Palù, G.; Romeo, D. Eur. J. Biochem. 2000, 267, 1715.

29. Tossi, A.; Benedetti, F.; Norbedo, S.; Skrbec, D.; Berti, F.; Romeo D. Bioorg. Med. Chem. 2003, 11, 4719.

30. Venkatesan, N.; Kim, B. H. Curr. Med. Chem. 2002, 9, 2243.

31. Chakravarty, P. K.; Combs, P.; Roth, A.; Greenlee, W. J. Tetrahedron Lett. 1987, $28,611$.

32. Benedetti, F.; Miertus, S.; Norbedo, S.; Tossi, A.; Zlatoidzky, P. J. Org. Chem. 1997, 62, 9348.

33. Mikolajczik, M.; Balczewski, P. Synthesis 1987, 659.

34. Benedetti, F.; Venturini, R. unpublished work.

35. Våbenø J.; Brisander, M.; Lejon, T.; Luthman, K. J. Org. Chem. 2002, 67, 9186.

36. Hoffman, R. V.; Maslouh, N.; Cervantes-Lee F. J. Org. Chem. 2002, 67, 1047.

37. Hoveyda, A. H.; Evans, D. A.; Fu, G. C. Chem. Rev. 1993, 93, 1307.

38. Benedetti, F.; Miertus, S.; Norbedo, S. Croatica Chem. Acta 2001, 74, 763.

39. Frecer, V.; Miertus., S. Macromol. Chem. Phys. 2002, 203, 1650.

40. Lipinski, C. A. ; Lombardo, F. ; Dominy, B. W. ; Feeney, P. J. Adv. Drug Delivery Rev. 1997, 23, 3. 